Article

\title{
Impact of COVID-19 Lockdown on the Fisheries Sector: A Case Study from Three Harbors in Western India
}

\author{
Ram Avtar ${ }^{1,2, *}$, Deepak Singh ${ }^{1,3}$, Deha Agus Umarhadi ${ }^{2} \oplus$, Ali P. Yunus ${ }^{4,5}$, Prakhar Misra ${ }^{6}(\mathbb{D}$, \\ Pranav N. Desai ${ }^{7}$, Asma Kouser ${ }^{8}$, Tonni Agustiono Kurniawan ${ }^{9}$ (D) and KBVN Phanindra 10 \\ 1 Faculty of Environmental Earth Science, Hokkaido University, Sapporo 060-0810, Japan \\ 2 Graduate School of Environmental Science, Hokkaido University, Sapporo 060-0810, Japan; \\ deha@eis.hokudai.ac.jp \\ 3 Department of Geography and Resource Management, The Chinese University of Hong Kong, Sha Tin, \\ New Territories, Hong Kong, China; deepaksingh@cuhk.edu.hk \\ 4 State Key Laboratory of Geohazard Prevention and Geoenvironment Protection, \\ Chengdu University of Technology, Chengdu 610059, China; pulpadan.yunusali@nies.go.jp \\ 5 Center for Climate Change Adaptation, National Institute for Environmental Studies, Tsukuba, \\ Ibaraki 305-8506, Japan \\ 6 Research Institute for Humanity and Nature (RIHN), Kamigamo, Kita-ku, Kyoto 603-8047, Japan; \\ mprakhar@chikyu.ac.jp \\ 7 Centre for Research in Environment, Science and Technology Policy (CREST), New Delhi 110057, India; \\ dpranav@jnu.ac.in \\ 8 Department of Economics, Bengaluru City University (BCU), Post Office Road, Ambedkar Veedhi, Bengaluru, \\ Karnataka 560001, India; asma11_isg@jnu.ac.in \\ 9 College of the Environment and Ecology, Xiamen University, Xiamen 361102, China; tonni@xmu.edu.cn \\ 10 Department of Civil Engineering, Indian Institute of Technology Hyderabad, Telangana 502285, India; \\ phanindra@ce.iith.ac.in \\ check for \\ * Correspondence: ram@ees.hokudai.ac.jp; Tel.: +81-011-706-2261
} updates

Citation: Avtar, R.; Singh, D.; Umarhadi, D.A.; Yunus, A.P.; Misra, P.; Desai, P.N.; Kouser, A.; Kurniawan, T.A.; Phanindra, K Impact of COVID-19 Lockdown on the Fisheries Sector: A Case Study from Three Harbors in Western India. Remote Sens. 2021, 13, 183. https://doi.org/10.3390/rs13020183

Received: 15 October 2020 Accepted: 28 December 2020 Published: 7 January 2021

Publisher's Note: MDPI stays neutral with regard to jurisdictional clai$\mathrm{ms}$ in published maps and institutional affiliations.

Copyright: (C) 2021 by the authors. Licensee MDPI, Basel, Switzerland. This article is an open access article distributed under the terms and conditions of the Creative Commons Attribution (CC BY) license (https:// creativecommons.org/licenses/by/ $4.0 /)$.
Abstract: The COVID-19 related lockdowns have brought the planet to a standstill. It has severely shrunk the global economy in the year 2020, including India. The blue economy and especially the small-scale fisheries sector in India have dwindled due to disruptions in the fish catch, market, and supply chain. This research presents the applicability of satellite data to monitor the impact of COVID-19 related lockdown on the Indian fisheries sector. Three harbors namely Mangrol, Veraval, and Vankbara situated on the north-western coast of India were selected in this study based on characteristics like harbor's age, administrative control, and availability of cloud-free satellite images. To analyze the impact of COVID in the fisheries sector, we utilized high-resolution PlanetScope data for monitoring and comparison of "area under fishing boats" during the pre-lockdown, lockdown, and post-lockdown phases. A support vector machine (SVM) classification algorithm was used to identify the area under the boats. The classification results were complemented with socio-economic data and ground-level information for understanding the impact of the pandemic on the three sites. During the peak of the lockdown, it was found that the "area under fishing boats" near the docks and those parked on the land area increased by $483 \%, 189 \%$, and $826 \%$ at Mangrol, Veraval, and Vanakbara harbor, respectively. After phase-I of lockdown, the number of parked vessels decreased, yet those already moved out to the land area were not returned until the south-west monsoon was over. A quarter of the annual production is estimated to be lost at the three harbors due to lockdown. Our last observation (September 2020) result shows that regular fishing activity has already been re-established in all three locations. PlanetScope data with daily revisit time has a higher potential to be used in the future and can help policymakers in making informed decisions vis-à-vis the fishing industry during an emergency situation like COVID-19.

Keywords: COVID-19; fishing; harbors; marine resources; food security; PlanetScope 


\section{Introduction}

The novel coronavirus SARS-CoV-2 or, popularly COVID-19 pandemic has largely limited human activities with multiple lockdowns in several parts of the world. The cumulative loss to global GDP in 2020-2021 due to the pandemic is estimated to be around \$9 trillion [1]. Even the sub-continental-sized India restricted its 1.3 billion population through the first lockdown on 24 March 2020. For India, despite various sustained efforts with lockdown featuring five different phases, the impact of COVID-19 has shown multi-sectoral spill-over effects [2,3]. According to the Centre for Monitoring Indian Economy (CMIE), a research think tank in India, nearly 27 million youth in the age group of 20-30 years lost their jobs in April 2020. The micro, small, and medium enterprises (MSMEs), as the second-largest employer after agriculture, involving 110 million workforces, are struggling to cope with this economic fallout [4]. The Indian economy has already contracted by $8.9 \%$ of GDP, as the businesses are daily losing around $\$ 8-16$ billion $[5,6]$. The impact of the pandemic is also seen in the fisheries sector, which is economically important to India's coastal states [7-11].

India has a vast coastline and its maritime states/Union Territory (UT) are the major contributor to the country's blue economy [12-14]. The blue economy is the sustainable use of ocean resources for economic growth, improved livelihoods, and jobs while preserving the health of the ocean ecosystem [15]. The fisheries sector contributes around $1.03 \%$ of India's GDP (2017-2018), with the export worth $\$ 7.1$ billion [16]. The country produces more than 12 million tonnes of inland and marine fisheries products annually, a third of which is through the marine route. According to the National Fisheries Development Board (NFDB) of India, the marine fisheries sector employs (directly and indirectly) more than 16 million fishing workers and their families in 3477 marine fishing villages across the seventy coastal districts of the country [13,17-19]. This highlights the importance of the Indian fishing industry and the coastal regions, both for livelihood and nutrition perspectives [20-22].

The state of Gujarat with a quarter of India's coastline contributes a fifth of the country's marine fishing production. The key employment opportunities for marine fishing in the harbor areas can be classified into four segments, viz., traditional/tidal fisheries workers (small-scale fishing operations), frontline fisheries workers (large-scale fishing operations), processing works (ice factories, packaging, sorting, etc.), and technical works (net repairs, crane operations, diesel and machine workshops, batteries and electrical works, vessel hauling with machines, and wood-based tasks and peripheral works on information and communication equipment) (Figure 1). Figure 1 illustrates the valuechain of marine fishing industries. The native fishing communities dominate the first two segments. While the migrant workers from the other states predominantly feature in processing and technical works.

Looking at the fish catching processes (Figure 1), the traditional/tidal fishing is only feasible in the provinces of Gujarat and West Bengal. It is conducted as a boatless operation during low tides when the water recedes 1000 to $1500 \mathrm{~m}$ from the sea-shore. In the state of Gujarat, tidal fishing constitutes nearly five percent of total volume and its catch is normally sold in the local markets [23,24]. Usually, fisherfolks living within 10-15 km of the coasts are involved in this domain [24]. Simultaneously, the frontline fisheries workers involved in sailing are predominantly from Koli, Kharwar, Vaghevar, and Machhi fishing communities living near the harbor areas. The marine fishing trips are of two types, viz., multiple days (normally two weeks or more) and a single day. The multiple day trips involve a crew of 8-10 or more members with Tandel (Vessel Captain), other fishermen, and two cooks $[24,25]$. Typically, motor fishing vessels (MFV) like trawlers and gillnetter are used for the multiple-days trip. Trawlers and gillnetters are boats of the same make, the only difference is on the kind of net used. These types of MFV vessels can do around twenty trips in a year and are also the machines associated with high capital $(\$ 70,000$ to $\$ 80,000)$ and operational-maintenance cost ( $\$ 10,000$ to $\$ 12,000$ per year) [24]. On the other hand, a single day trip involves a crew of 2-3 members through Fiber Reinforced Plastic (FRP) 
boats [24,25]. The make of motors installed on FRP decides its nomenclature and price. The FRP boat can cost somewhere between $\$ 3000$ to $\$ 4000$ with an operational-maintenance lower than $\$ 1000$ per year [24].

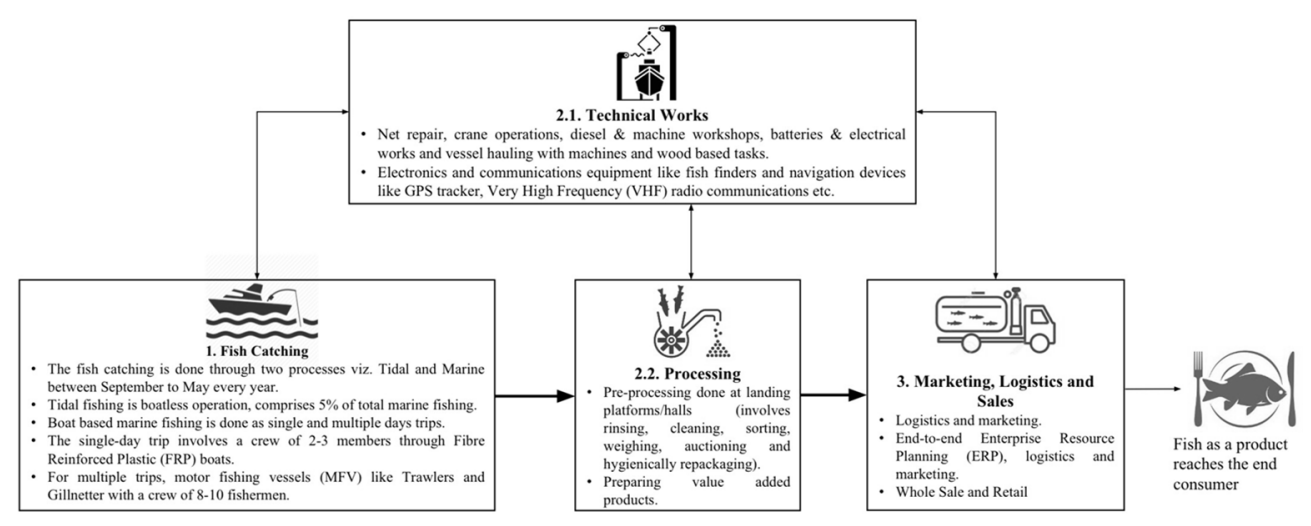

Figure 1. The value-chain of the Marine Fishing Industry (Source: Compiled by the Authors).

Initially expecting a shorter duration lockdown due to COVID-19, the fishermen parked their boats in the harbor areas. This created a huge influx of fishermen and workers left idle in congested dwellings lacking essential amenities like food, water, and electricity [18,26-28]. After the first lockdown, anticipating a prolonged effect of the pandemic, the fishermen and the migrant workers left (towards their native places) the harbor townships by stably parking the boats [29-31]. The Central Government's exemptions for the fisheries sector in April 2020, had little bearing [32]. This was because although the restrictions to do fishing was eased, yet the nation was still under lockdown [24]. The sudden lockdown eventually pushed the fisheries workers into a vicious cycle of hunger, unemployment, and debt trap (loans from vessel owners and local business merchants). This makes it prudent to understand the impact of lockdown on various dimensions of the fisheries sector.

Using the geospatial techniques [33] combined with socio-economic data and other ground-level information can play a crucial role in highlighting the impact on the fisheries sector during the COVID-19 related sudden lockdown. There have been various applications of remote sensing data in detecting sites for fish-catch [34], habitat identification [35,36], fish productivity [37], fishing hot spots [38], and detection of fishing vessels [39]. Yen et al. [36] have used moderate resolution imaging spectroradiometer (MODIS) satellite data to derive sea surface temperature, chlorophyll- $a$, sea surface height, and sea surface salinity to study habitat suitability of yellowfin tuna in the Pacific ocean. Klemas [40] summarized the advantage of applications of advanced remote sensing techniques in the fisheries sector, such as (i) help to manage sustainable development of fisheries, (ii) identify habitats attractive to fish aggregation, and (iii) determine the sensitivity of fish species to sea surface temperature. These techniques can be deployed in the estimation, near real-time monitoring, and management of fishing vessels. Moreover, remote-sensing can help with the identification of appropriate fishing grounds and the control of overfishing. Collectively these techniques can contribute towards the Sustainable Development Goals (SDGs\#14) by promoting sustainable fishing [11,41,42].

This study aims to monitor the spatio-temporal changes in boat coverage area at the three harbors in the western state of Gujarat and the UT of Daman and Diu during the COVID-19 related lockdown. The quantification of the area covered under boats at the harbors and in its vicinity is conducted using high-resolution PlanetScope data. The PlanetScope images-based estimates of the area covered by boats are seen in the light of socio-economic and ground-level data to understand the impact of lockdown on fisheries and allied sectors at the three sites. The methods and approach in this study can potentially help the policymakers in designing resilient and sustainable systems for the fishing industry in response to sudden emergencies (like lockdown) in India or elsewhere. 


\section{Materials and Methods}

\subsection{Study Area}

The study area is located in the western part of India in the state of Gujarat and UT of Daman and Diu, which has a quarter of India's mainland coastline. Historically all forms of fishing, viz., marine, estuarine, riverine, and freshwater, are conducted in this region [23]. This study is focused on three harbor areas, i.e., Mangrol and Veraval in Junagadh and Gir Somnath districts of Gujarat, and Vanakbara in the UT of Daman and Diu (Figure 2). Figure 2 shows the locations of the study sites in the Gujarat state of India. The selection of study sites is based on their characteristics and availability of cloud-free satellite images.

The Mangrol and Vanakbara fishing harbors have been recently modernized for large volumes of vessels, fisheries workers, and their families. The Veraval is one of the oldest fishing harbors in Gujarat can only accommodate about fifteen thousand fishing families [43]. The difference in the antiquity of harbors can also help in gauging the propensity of new and old harbors towards the imminent challenges. Another differentiating feature is about administrative control of these harbors. The Vanakbara is under the UT administration, which is under the aegis of the central government, and the other two are with the provincial government of Gujarat. Varying administrative control also influences the operational performance of these harbors [24].

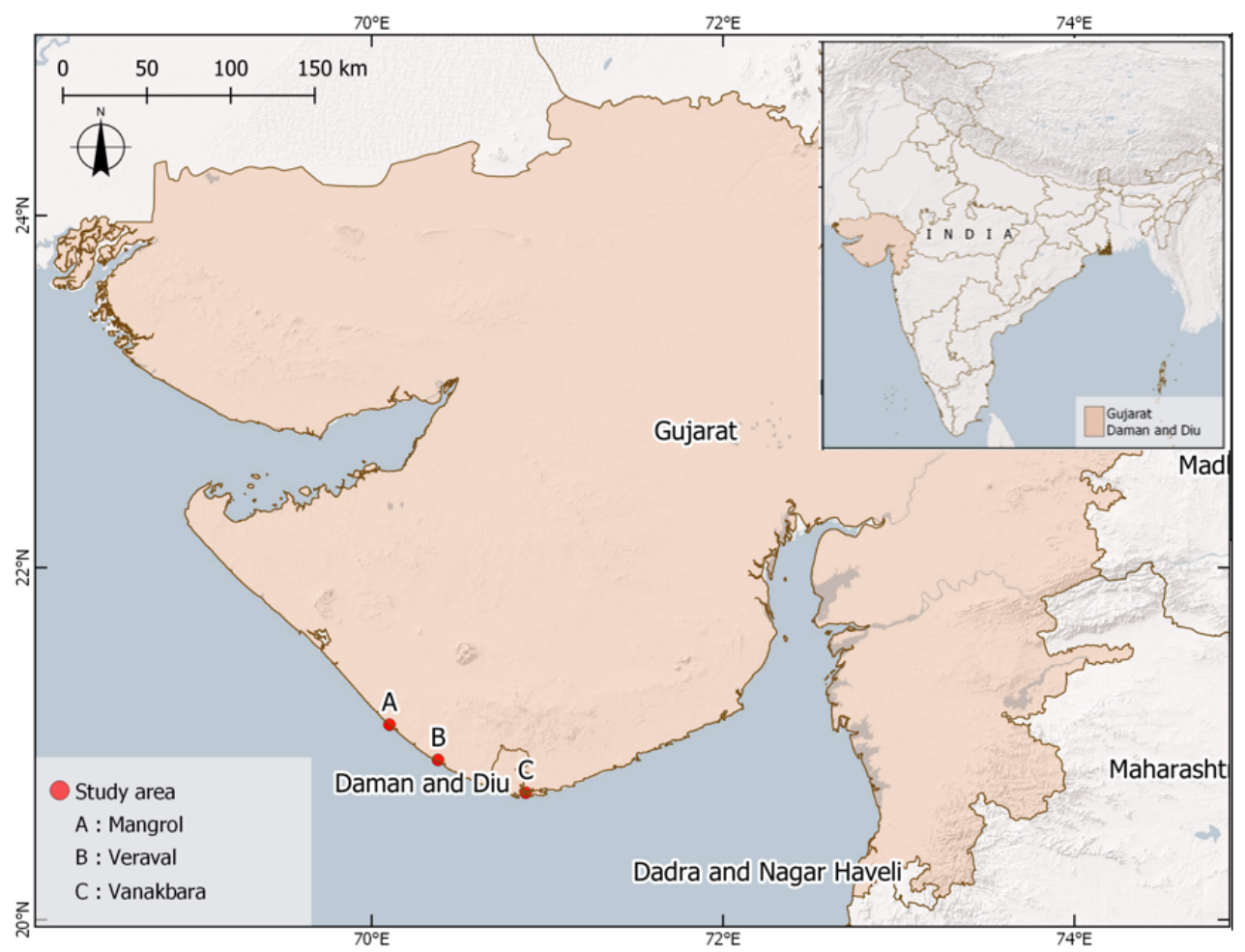

Figure 2. Study area map showing the location of the three studied harbors (A: Mangrol, B: Veraval, and C: Vanakbara).

\subsection{Remote Sensing Data}

This research used 24 PlanetScope images covering the study area in eight timespans, corresponding to lockdown phases, as listed in Table 1 and shown in Appendix A (Figures A1-A3). The images were downloaded from the https://www.planet.com/. PlanetScope images are multispectral data comprising of 4-bands in the visible-infrared electromagnetic spectrum. The advantage of Planet constellation satellite over other imageries is that they can capture the same location daily with 3-meter pixel size along with 16-bit radiometric resolution $[44,45]$. The movement of fishing boats in the harbors during the pre-lockdown, lockdown and post-lockdown periods was monitored with the help of 
Planet images. Table 1 provides details about the acquisition dates of images during the different phases of lockdown. The images in unlock 2.0 (1 to 31 July 2020) and 3.0 (1 to 31 August 2020) stages were not included due to the absence of cloud-free images during this time. All the downloaded images are in the ortho-rectified surface reflectance (SR) level after being corrected using 6SV2.1 radiative transfer code and MODIS NRT data by the provider. The images were acquired between 0900 and 1140 Indian Standard Time (IST). Fisherfolks in Gujarat mostly used mechanized boats, where fishing trips can last between two to three weeks [29]. Hence this study assumes that the more vessels docked in the harbor area indicate lesser fishing activity, regardless of the image acquisition time.

Table 1. List of PlanetScope images used in this study.

\begin{tabular}{|c|c|c|c|}
\hline \multirow{2}{*}{ Lockdown Stage } & \multicolumn{3}{|c|}{ Acquisition date } \\
\hline & Mangrol & Veraval & Vanakbara \\
\hline Pre-lockdown & 20 March 2020 & 20 March 2020 & 17 March 2020 \\
\hline Phase I & 30 March 2020 & 28 March 2020 & 28 March 2020 \\
\hline Phase I & 16 April 2020 & 14 April 2020 & 14 April 2020 \\
\hline Phase II & 3 May 2020 & 3 May 2020 & 2 May 2020 \\
\hline Phase III & 16 May 2020 & 17 May 2020 & 16 May 2020 \\
\hline Phase IV & 30 May 2020 & 29 May 2020 & 26 May 2020 \\
\hline Unlock 1.0 & 11 June 2020 & 18 June 2020 & 11 June 2020 \\
\hline Unlock 4.0 & 4 September 2020 & 3 September 2020 & 7 September 2020 \\
\hline
\end{tabular}

\subsection{Methods}

The use of high-resolution satellite data to pinpoint individual vessels in the open sea is well researched and commonly applied technique. This involves approaches based on the threshold, salient, shape and texture, statistics, transfer domain, computer vision, and deep learning methods [46]. Many studies detected inshore vessels using very high resolution $(<1 \mathrm{~m}$ spatial resolution) satellite data for precise extraction of the objects [39,47-50]. Currently, the majority (over 98\%) of registered boats at the three harbors are motor fishing vessels (MFV) and fiber-reinforced plastic (FRP) [29]. Generally, an MFV and FRP boat measures around 17 to $18 \mathrm{~m}$ and 9 to $10 \mathrm{~m}$, respectively [25,29,31,51]. Figure A4 shows the pictures of boats parked from the study area (Figure A4a-d). Detection of individual boats/vessels in the harbor area is relatively difficult due to the high similarity of tone and texture between vessels and the sandy surfaces [47]. Individual boats counting could not be accommodated using 3-m PlanetScope data in this study. Figure A1c shows the zoomed image of PlanetScope data and it was difficult to identify individual boats using visual interpretation. Therefore, this study is focused on identifying the changes in the area covered under the fishing boats/vessels.

The classification procedure is divided into two parts: (i) the identification of the area of boats in the sea, and (ii) on the land area. The sea area consists of boats that are docked in the harbor and its vicinity area. While the land area is for boats that are moved out of the water and parked in the boat parking area. For the sea area procedure, the sea-land separation was conducted as the first basic workflow in boat detection [46]. The land area was digitized manually by using high-resolution imagery and used as the land mask. Further, image classification was used to detect the areas covered by fishing boats near harbors. The multispectral classification was applied to distinguish boats from other classes by using the support vector machine (SVM) method in ENVI software. SVM algorithm is the most common classification method applied by previous studies in ship detection [46]. We used four multispectral bands of PlanetScope data and NDWI (Normalized Difference Water Index) images to enhance the water object [52]. The NDWI values were calculated using the following equation [53]:

$$
N D W I=\frac{R_{\text {Green }}-R_{N I R}}{R_{\text {Green }}+R_{N I R}}
$$


where, $R_{\text {Green }}$ and, $R_{N I R}$ denote reflectance value of green and near-infrared band, respectively. In the SVM classification, the radial basis function (RBF) was selected for the kernel type parameter with the gamma value of 0.2 based on the number of bands used. The boat detection on the land area was carried out by visual interpretation of PlanetScope data. This is because of errors introduced while applying the same multispectral classification due to the spectral signature of vessels/boats being relatively similar to sandy beaches and the settlement area.

The accuracy assessment was conducted by delineating the fishing boat objects on the very-high-resolution image, Google Earth image, as one of the reference data used in remote sensing-based thematic mapping [54]. The images are provided by Maxar Technologies based on very high spatial resolution satellite imagery and presented in $30-\mathrm{cm}$ pixel size [55]. This method substitutes in situ measurement as reference data during the lockdown state. The Google Earth images are only available for 14 May 2020 in Mangrol and 28 May 2020 in Veraval sites. The first mentioned image was used to validate the classification of 16 May 2020 at Mangrol harbor. Similarly, the image of 28 May 2020 was used to validate the classification results at Veraval harbor dated 29 May 2020. The validation was not performed at Vanakbara harbor because Google Earth images were unavailable during the monitoring period.

Our validation used the area-based accuracy assessment considering the correctness and completeness of classified objects [56]. Correctness is defined as the percentage of extracted objects that are correctly classified. In contrast, completeness is the percentage of objects in the real world (reference data). These are explained by the extracted objects, and overall quality refers to a percentage of matched objects among the total objects in both classification results and reference data [56]. This assessment is focused on the particular object; hence, it is suitably used in this study which aims to identify only the boat as an object. Adopting the methods by Whiteside et al. [57] and Kamal, et al. [58], circular buffers were used for each validation site with a radius of $30 \mathrm{~m}$.

Apart from the vessel detection methods, the image results were analysed in the light of primary ground-level information received through personal interviews of office bearers of the national fisheries workers forum (NFF) of India and other publicly available socioeconomic data like annual production, vessels registered, people working and staying at the harbor, basic living conditions, etc. Date wise communication strategies (by NFF) and various public notifications/orders by Central and the State Governments were also taken into account.

\section{Results}

The SVM classification algorithm was applied to PlanetScope data to obtain the classified maps of the area covered under the boats. The higher spatiotemporal resolution of the PlanetScope constellation satellite enables capturing the vital changes on land features [59]. The high-resolution satellite data can be used as a proxy to represent the real condition in the study area. It is because the collection of field data was not possible during the lockdown. The fishing boats delineated through visual analysis of high-resolution Google Earth image was used as the reference data to validate the outcome of PlanetScope based classification results.

Figures 3-5 depict the results of the area under boats at Mangrol, Veraval, and Vanakbara harbors, during the pre-lockdown, lockdown (phase I-IV), and unlocking (unlock 1.0 and 4.0) phases, respectively. Generally, under normal operations, the fisheries workers temporarily park their vessels within $3-5 \mathrm{~km}$ vicinity of the harbor. However, due to the suspension of all fishing and related activities during the lockdown phase, a sudden increment in the area under boats is witnessed in these images. Figure 6 illustrates time-series trends in the area under boats during different lockdown phases at the three sites. 


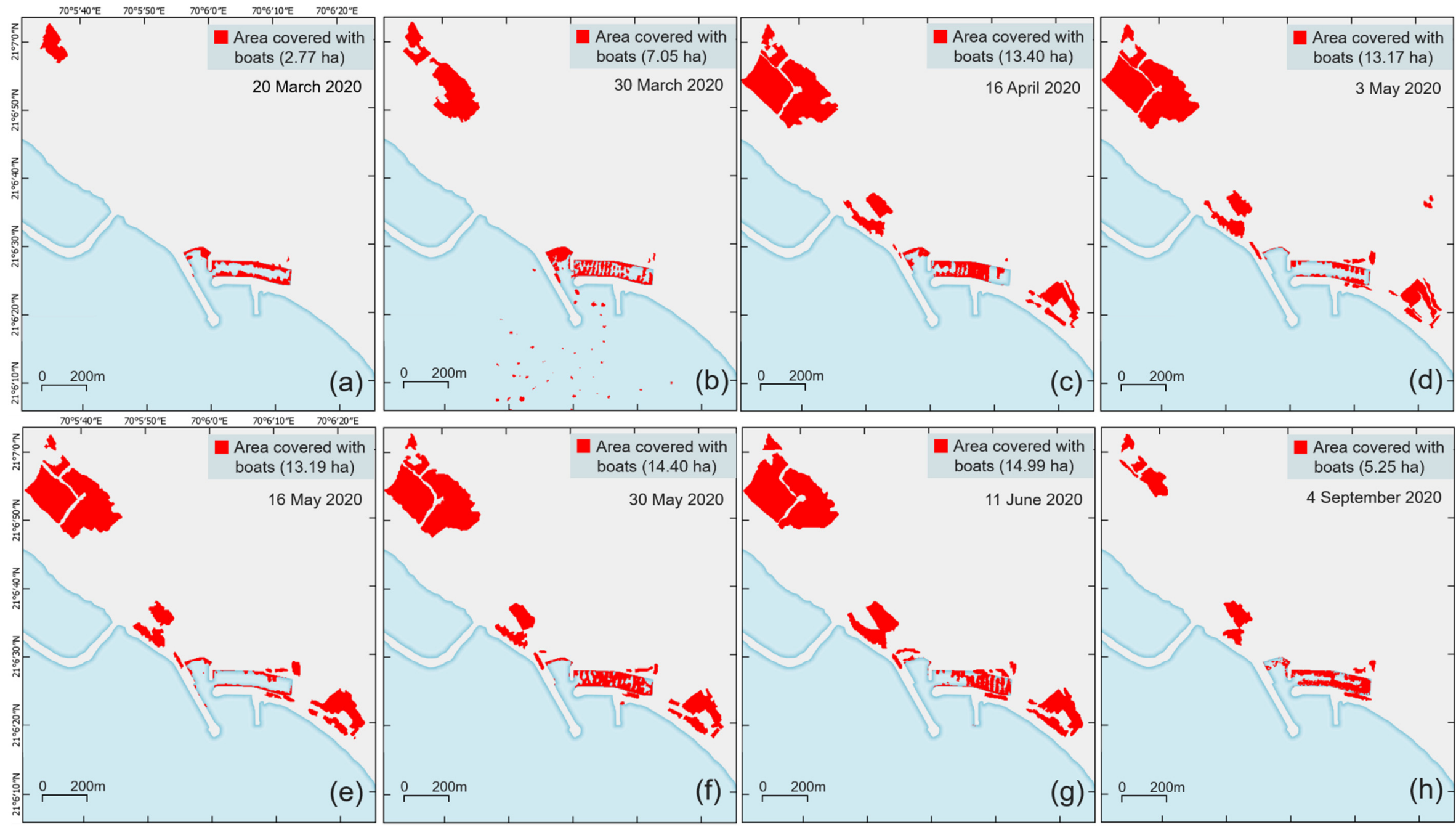

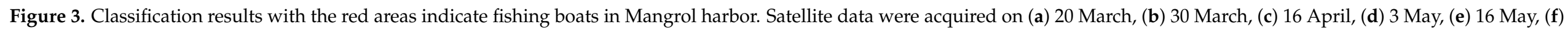
30 May, (g) 11 June, and (h) 4 September 2020. 

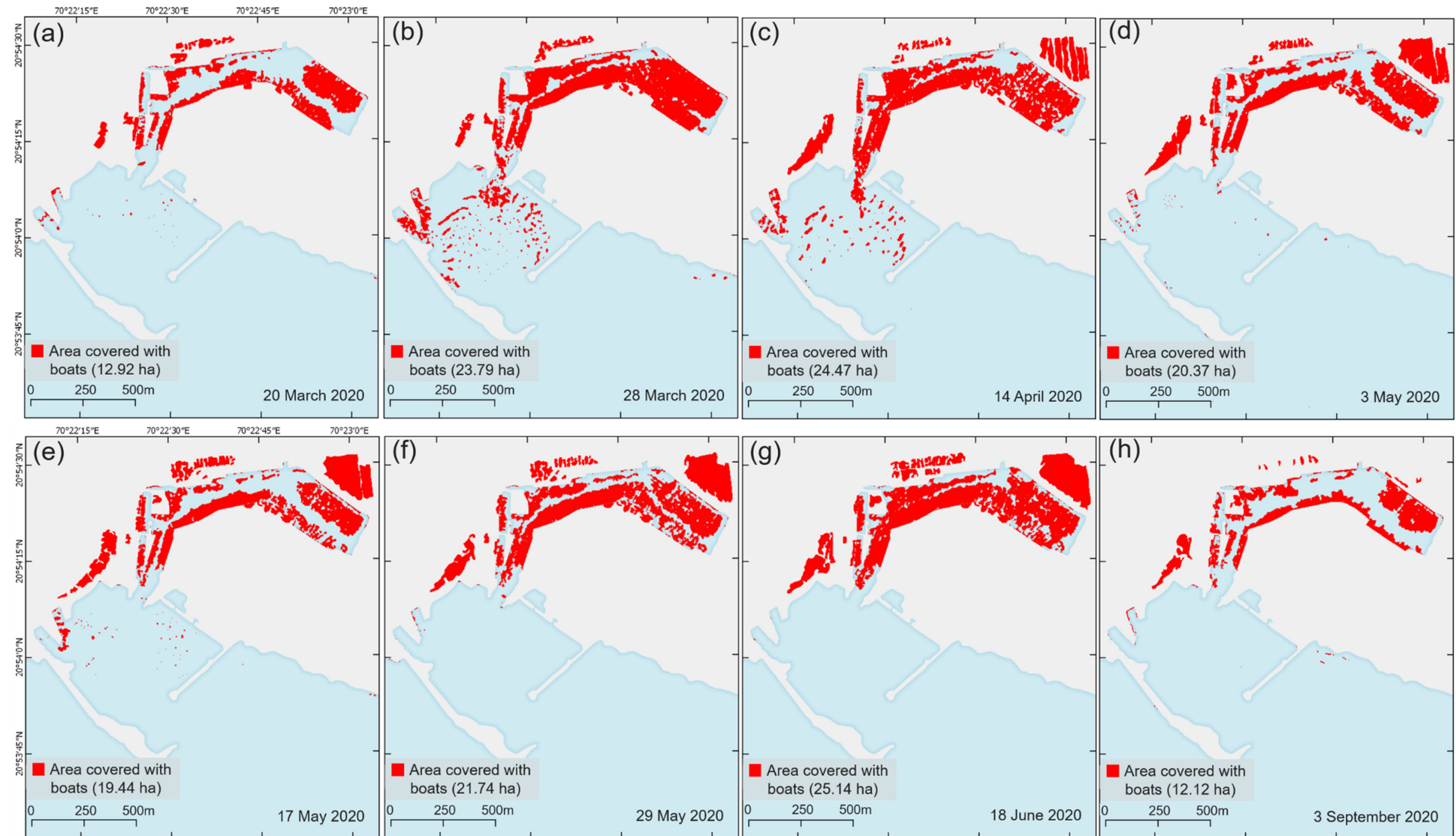

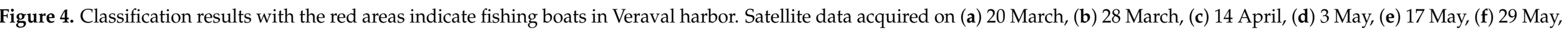
(g) 18 June, and (h) 3 September 2020. 

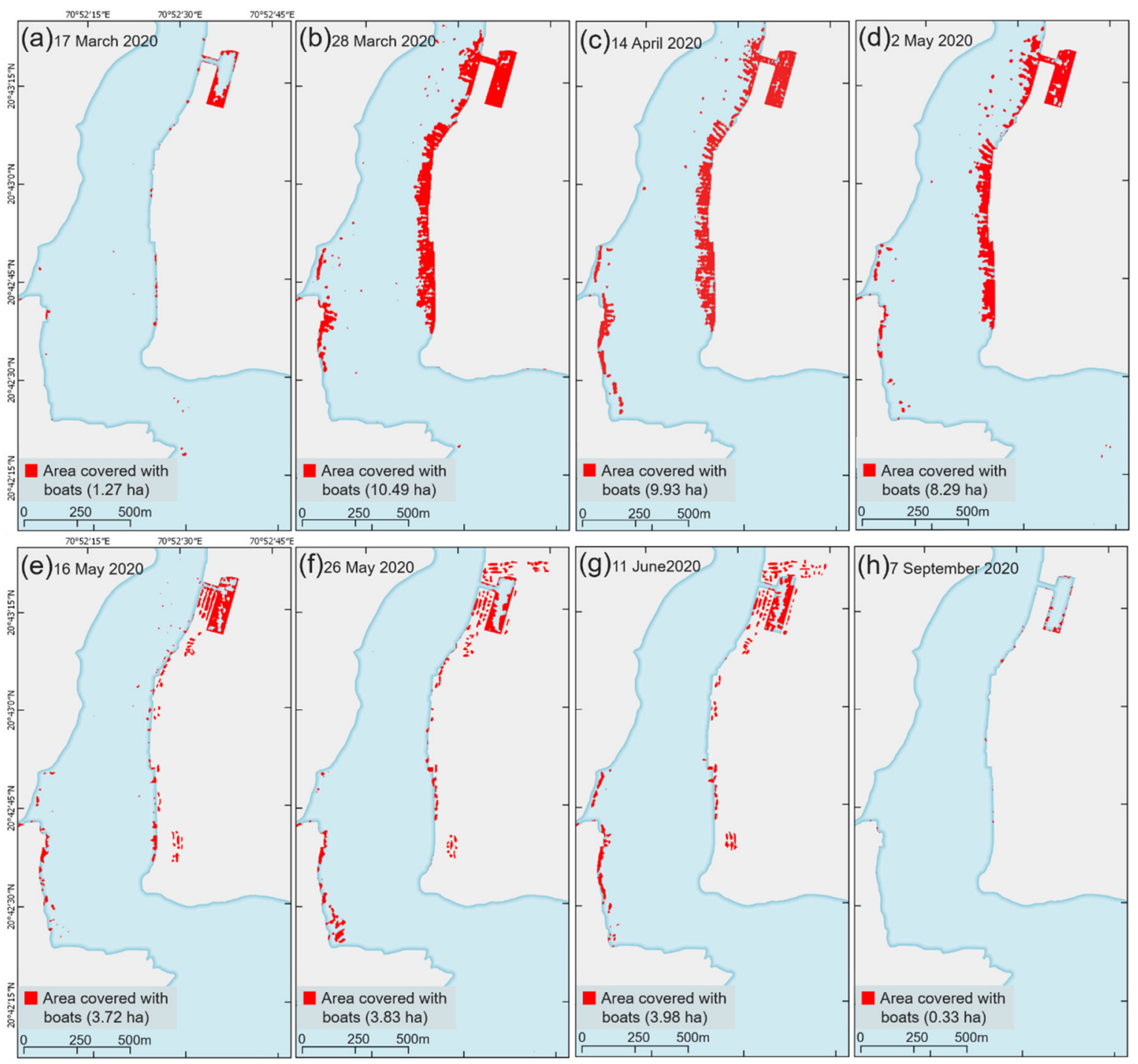

Figure 5. Classification results with the red areas indicate fishing boats in Vanakbara harbor. Satellite data acquired on (a) 17 March, (b) 28 March, (c) 14 April, (d) 2 May, (e) 16 May, (f) 26 May, (g) 11 June, and (h) 7 September 2020.

At Mangrol, during the pre-lockdown period (on 20 March 2020), the total area covered under the boats was 2.77 ha (Figures 3a and 6). However, anticipating the uncertainty during the pandemic and successive extensions of the lockdown, the fisheries workers preferred safer and long-term parking near the land area. Consequently, the area under boats at Mangrol harbor rose sharply during the lockdown phases from 7.05 ha (30 March $2020)$ to 13.40 ha (16 April 2020), respectively. This slightly decreased to 13.19 ha only after the relaxation of lockdown (at the end of phase-III).

At Veraval harbor (Figure 4a) the total area covered under the boats was 12.92 ha in the pre-lockdown stage (20 March 2020). It increased to 23.79 ha during the first phase of lockdown (28 March 2020). As reflected in Figure 4b, the harbor was overwhelmed by anchored boats after the sudden lockdown. Consequently, the boats parked on land increased significantly in the following period (Figure $4 \mathrm{c}, \mathrm{d}$ ). The ground information provided by fishermen confirms this nature of vessels parked on the land as well as sea area in the vicinity of the harbors. Figure $4 \mathrm{e}$, shows a decrease in the boats covered area to 19.44 ha at the end of lockdown Phase-III (17 May 2020). 


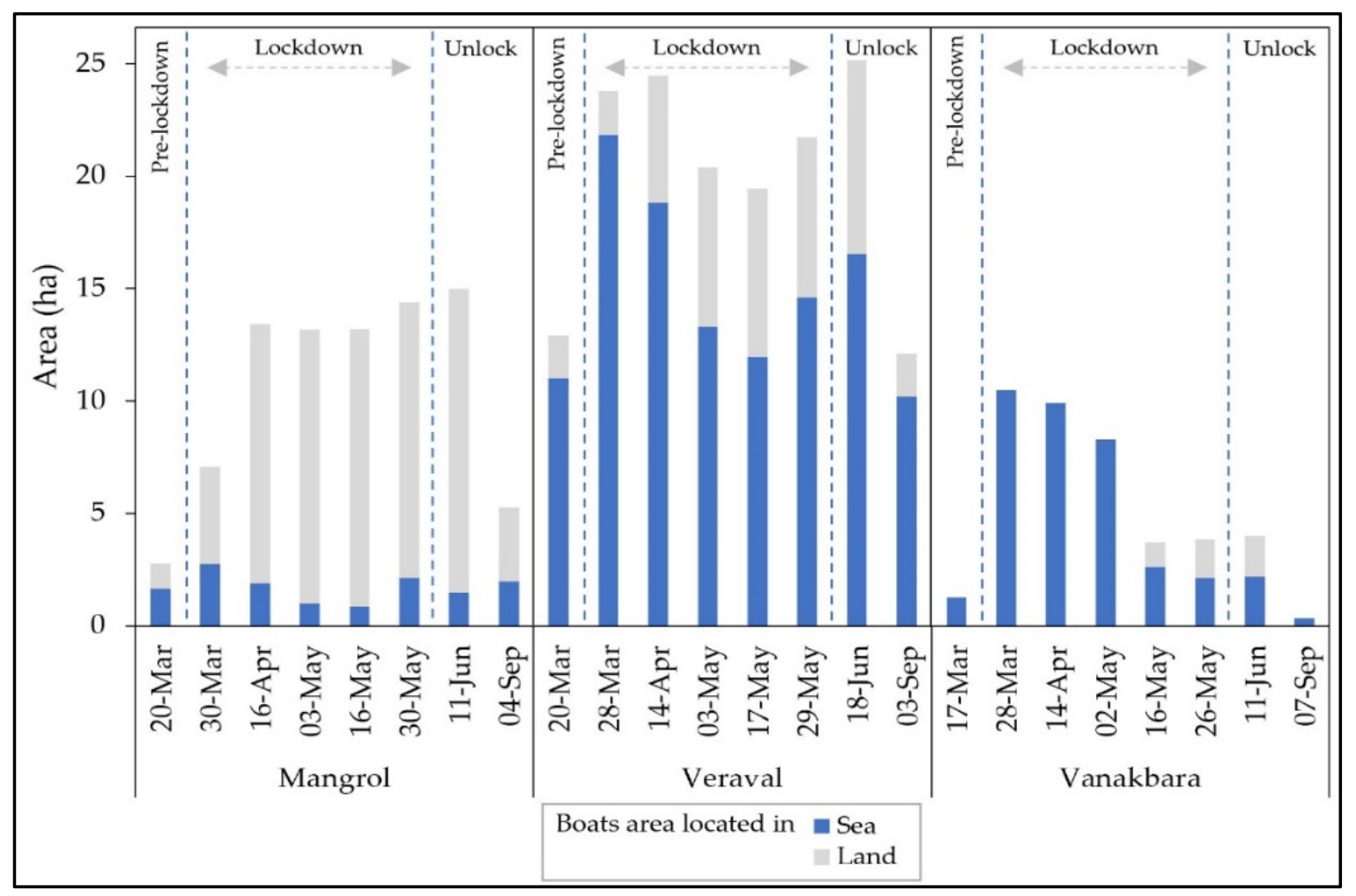

Figure 6 . The area of boats detected by image classification in the sea and land area.

Both Mangrol and Veraval have limited parking spaces on the seaside. Due to this, the total area under boats varied over the observation dates. Initially (phase-I), the parked boats on the land area rose exponentially, until the unlock 1.0 stage. Thereafter, in the following phases, a gradual increase was observed. The paucity of space at Mangrol and Veraval also interferes with the maintenance schedule of the vessels [24]. If the space issues are not addressed, it can limit the operational performance of the fishing fleets from these harbors.

The area covered under boats at the Vanakbara harbor shows a different trend when compared to Mangrol and Veraval. The area of boats anchored at the Vanakbara harbor in the pre-lockdown stage is only 1.27 ha (Figure 5a). This increased drastically to 10.49 ha at the beginning of the lockdown phase-I (Figure 5b). However, the boats parked on the land area were not observed in Vanakbara harbor during Phase-III (Figure 5b-d). This is due to its location in the river estuary, and the Vanakbara port has ample temporary parking space available in its vicinity. Contrarily, fishermen in Mangrol and Veraval started to park their vessels on the land area just after the lockdown was announced because of limited capacity at these harbors [60]. At Vanakbara, by 14 April 2020, the area under boats decreased slightly to 9.93 ha (Figure 5c). It was only by phase III, like the other two harbors, the fishermen at Vanakbara (on 16 May 2020) also started moving their boats to the stable land surfaces (Figure 5e), even though the vicinity area was enough to accommodate the vessels. Overall, the area covered by fishing boats in the sea area decreased after phase-I for all three sites (Figure 6).

During the unlock 4.0 stage, the areas covered by boats in all three harbors decreased significantly, especially from the land parking area. In Mangrol, the boats parked on the land decreased $76 \%$ from our previous observation date (11 June 2020). Similarly, in Veraval, there is a decrease of $77 \%$ of boats covered area that is located on the land (Figure 6). By 7 September 2020, significantly lesser areas (only $0.33 \mathrm{ha}$ ) were witnessed under docked boats in the Vanakbara harbor (Figure 6). Due to the south-west monsoon (1 June to 31 July) season fishing restrictions by the Government, the fishing workers who had resumed their activities after phase-II lockdown relaxations had to return to their harbors. It is a 
periodic restriction imposed every year to enable fish spawning during the monsoon. This also increased the number of boats parked at the harbor areas [61,62]. For instance, the rise in parked vessels at the Veraval (18 June 2020, Figure 4g) is also due to this reason.

For accuracy assessment, a total of six and five sample areas were selected randomly in Mangrol and Veraval harbors, respectively (Figure 7a,b). Although the Google Earth image acquired at Veraval was hazy, it is possible to interpret boat objects from the image. Only the boats located on the land area were considered for accuracy assessment to avoid the difference of a few days in image acquisition by PlanetScope and Google Earth images. The boats located in the sea might move within a few days gap of image acquisition. Figure $7 \mathrm{c}, \mathrm{d}$ shows the comparison of the area covered under the boats based on the classification of PlanetScope and high-resolution Google Earth images. These results elucidate that the classified boat area (yellow colour) is underestimated as compared to reference data (cyan colour) at both sites (Figure 7c,d). The underestimation is due to the lower spatial resolution ( $3 \mathrm{~m}$ ) of PlanetScope data, which contains ambiguous mixed pixels leading to the unclassified objects in some areas. The overclassified area also appears particularly in the gap between the boats; however, this is less than the underestimation.

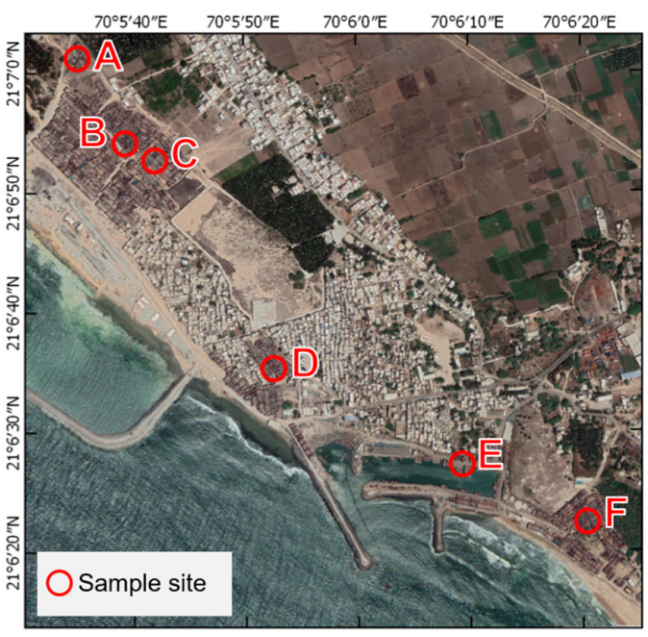

(a)
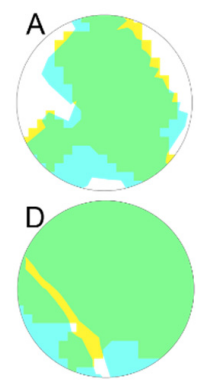

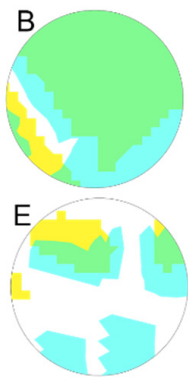

(c)

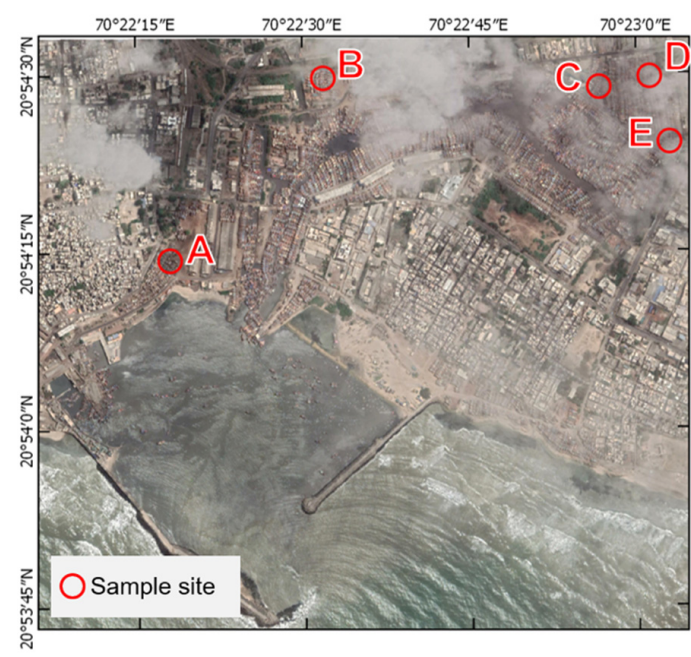

(b)
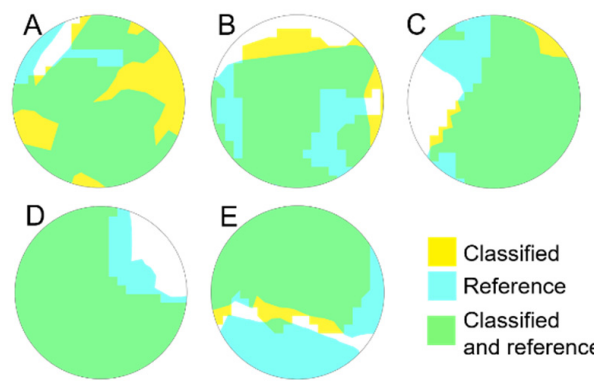

(d)

Figure 7. Circular sample sites for accuracy assessment in (a) Mangrol and (b) Veraval with the background of Google Earth image used for the reference. The classification results of boats in comparison with reference at sample sites located in (c) Mangrol and (d) Veraval.

The framework of area-based accuracy assessment generated the value of correctness, completeness, and overall quality of the validation results, as shown in Figure 8. Our results produced a high consistency of obtained results as compared with the reference data indicated by more than $88 \%$ of correctness, yet the completeness is lower than correctness 
(83.53\% and $80.49 \%$ ), explaining the underestimated results by PlanetScope data. The overall quality values in both Mangrol and Veraval are $78.60 \%$ and $73.14 \%$, respectively. Although the overall quality is below $80 \%$, all parameters (correctness, completeness, and overall quality) show a consistent pattern among the harbors. Based on this assessment, we assumed that the other classification results might produce similar accuracy.

Synergistic use of remote sensing-based results with socio-economic and ground-level data can help in understanding the structural issues at the three harbors. For instance, looking at the percentage change in area covered under the parked boats along with the statistical data like the total number of fisheries workers, fishing cycles, registered boats, and annual production can provide a better understanding of the micro-level impact of lockdown on different actors at these harbors. A generalization of these results to other harbors can also help in gauging the macro-level impact on the fisheries sector in India.

\begin{tabular}{|c|c|c|c|c|c|}
\hline \multirow{6}{*}{ 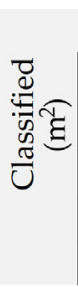 } & \multicolumn{5}{|c|}{ Reference $\left(\mathrm{m}^{2}\right)$} \\
\hline & & Boat & Non boat & Total & Correctness \\
\hline & Boat & 11454.32 & 857.70 & 12312.01 & $94.03 \%$ \\
\hline & Non boat & 2260.17 & 2399.74 & 4659.91 & \\
\hline & Total & 13714.49 & 3257.44 & & \\
\hline & Completeness & $83.52 \%$ & & Overall Qu & ality $78.60 \%$ \\
\hline
\end{tabular}

(a)

\begin{tabular}{|c|c|c|c|c|c|}
\hline \multirow{6}{*}{ 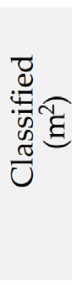 } & \multicolumn{5}{|c|}{ Reference $\left(\mathrm{m}^{2}\right)$} \\
\hline & & Boat & Non boat & Total & Correctness \\
\hline & Boat & 9426.50 & 1176.89 & 10603.39 & $88.90 \%$ \\
\hline & Non boat & 2284.93 & 1252.24 & 3537.18 & \\
\hline & Total & 11711.44 & 2429.13 & & \\
\hline & Completeness & $80.49 \%$ & & Overall Qu & Iality $73.14 \%$ \\
\hline
\end{tabular}

(b)

Figure 8. Confusion matrix of classification results for accuracy assessment in (a) Mangrol and (b) Veraval.

\section{Discussion}

The marine fishing industry in the western parts of India operates in full swing for around nine months from September to May every year. Annually, the fishing communities in this region cease their sailing operations in concordance with government regulations and the southwest monsoon (June-August), considering the fish-hatching season and inclement weather. Hence, shutting down the sailing operations for ten to twelve weeks is something with which the fishing communities and associated actors at these harbors are familiar. Usually, during this period the fishing communities engage themselves in the tasks like scheduled maintenance of vessels (Figure A4e,f) as well as pursuing family activities like marriage, visiting relatives, and construction/repair of houses [24]. Except sailing, other tasks, and economic activities at the harbor area function without any hindrances. However, the COVID-19 specific lockdown intensified the dormant challenges to the working class and harbor infrastructure.

The results from spatio-temporal analysis indicate that the regular fishing activities came to a stand-still for almost ten weeks (between March to May 2020). The fishing operations further continued to be impeded for another three months (June to August) due to the monsoon restrictions. During this period, the number of boats parked at all three harbors swelled. Despite the lockdown relaxations (after 11 April 2020) for the fisheries sectors, the area covered with boats was still higher in comparison to the pre-lockdown stages. According to the ground sources [24], in comparison to the previous financial year 
(FY), although the number of fishing and other workers along with MFV and FRP boats rose at these harbors, the overall fish and prawn's production declined by a quarter during the financial year 2020-21 at the three harbors (Table A1).

Nearly, 11,600, 25,650, and 8855 fishermen; and 2100, 16,100, and 4794 other workers are engaged at the Mangrol, Veraval, and Vanakbara harbors, respectively (Table A1). The monthly income of the fisheries and other technical workers ranges around \$300-500 and \$150-200, respectively [24]. Since many MFV vessel merchants are also badly hit due to high capital and operational-maintenance expenses, the impact is seen on wage reductions for all sections of working classes [24,25]. The non-operation of vessels for such a long period has pushed these fishermen and other workers into the vicious cycle of unemployment and debt burden [24,63]. In the future, the synergistic use of geospatial techniques with grassroots information can be a credible input for harbor administrators. Through this method, the actors responsible for harbor management at 1265 fish landing sites in India can also look for an immediate assessment of the challenges and award relief packages and contingencies during any disaster or uncertain event [64].

Another observation was that the design and administrative control of the harbor also influenced its operation during the lockdown. Vanakbara harbor, which is newly reconstructed and comes under the central government's jurisdiction, had shown better parking arrangements and smooth revival of business in the post-lock down scenario. Furthermore, Vanakbara was more sparsely populated with a lesser number of registered vessels than Mangrol and Veraval. The high concentration of workers and registered boats with a lack of temporary parking avenues at Mangrol and Veraval is an indicator of over-stressed infrastructure. For instance, the Veraval harbor is designed for 15,000 families, but the number of fisheries and other workers alone is more than 41,000 (Table A1) [43]. Interestingly, despite the recent modernization of Mangrol harbor, its infrastructure could not efficiently handle the lockdown pressure. The authorities responsible for the modernization programs need to address these issues.

At the macro-economic level, around a quarter of production has reportedly been lost during the lockdown (Table A1). However, the psycho-social effect due to unemployment and debt burden can have a serious and long-term impact on the fisheries workers associated with the three harbors [24,63]. If not corrected, similar emergencies in the future might have severe consequences for these or other harbors with resembling conditions in the country. In the future, the inferences from the conditions generated from sudden lockdown, if combined with geospatial analysis can help in planning or rejuvenating the infrastructure, relocation strategies, harbor extension, creation of new parking bays, and provisions for basic facilities like housing, water, electricity, etc. The information derived from this study can be useful in the planning and evacuation strategies, as well as socio-economic impact assessment.

The high-resolution satellite data-based information can be an excellent decisionmaking tool. PlanetScope data has played an important role in this study with a daily revisit cycle, which is typically higher than other optical satellite data. Detection of individual vessels using very high-resolution images might provide more useful information. Aerial images captured by unmanned aerial vehicles (UAV) with the flexibility of acquisition can be used for the detection of individual vessels $[65,66]$. However, the deployment is practically impossible during the lockdown situation. Very-high-resolution satellite data, such as Worldview and Pleiades, are costly to cover multi-temporal data for several sites.

As a limitation of this study, our method is not capable of counting the individual vessels using PlanetScope data. Moreover, the ambiguity lies in the regions where the boats were parked inland since the spectral reflectance of vessels is quite similar to sandy coastal areas. Future studies should also investigate the detection of individual fishing vessels using 3-m PlanetScope data, as many previous studies have already successfully applied it on very high spatial resolution images $(<1 \mathrm{~m})$ [46]. The use of deep learning algorithms can provide a better estimation of individual vessel detection. 


\section{Conclusions}

This work reveals that the fisheries activity in India was severely affected during the state of nationwide lockdown. The COVID-19 specific lockdown leaves fisheries workers stranded from sailing and operational tasks. By monitoring the temporal changes in the area covered under the boats during pre-lockdown, lockdown, and post-lockdown phases in the study area using high-resolution PlanetScope imagery, we showed the utility of remote sensing technology as a tool for tracking COVID impacts in the fisheries sector. PlanetScope data having $3 \mathrm{~m}$ resolution and daily revisit capability enables near real-time monitoring of area under the interest with high chances of cloud-free image acquisition as compared to other optical satellite data. The supervised machine learning classification results show the temporal pattern of the area covered by boats in sea and land. During the peak of the lockdown, the area covered by boats has increased by $483 \%, 189 \%$, and $826 \%$ at Mangrol, Veraval, and Vanakbara harbors, respectively. After phase-I of lockdown, the number of parked vessels decreased, yet those parked on land-surface were not returning until the south-west monsoon was over. This suppressed the production by a quarter at the three harbors, if compared to the previous year. At last, PlanetScope data, as well as personal interviews with stakeholders, confirmed that after the departure of the south-west monsoon, the fishing activity is slowly gaining normalcy. The study demonstrates how geospatial technology can be utilized for monitoring the activities of the fishing industry during an emergency state like lockdown. The concept can be used as a tool for planning and decision-making for fisheries and other sectors in similar or comparable situations. The information can be more useful by identifying individual boats using other high-resolution satellite or UAV data in the future.

Author Contributions: Conceptualization, R.A. and D.S.; methodology, R.A., A.P.Y., D.A.U., P.M. and K.B.V.N.P.; software, R.A., A.P.Y., D.A.U., P.M. and K.B.V.N.P.; validation, R.A., D.S. and DAU; formal analysis, R.A., P.M. and A.P.Y.; resources, R.A.; writing-original draft preparation, R.A., D.S., D.A.U., A.P.Y., P.M. and P.N.D.; writing-review and editing, R.A., D.S., D.A.U., A.P.Y., P.M., P.N.D., A.K., K.B.V.N.P. and T.A.K. All authors have read and agreed to the published version of the manuscript.

Funding: The publication fee was supported by Publication Support Grants of Hokkaido University, Japan.

Data Availability Statement: The datasets generated in the current study are available from the corresponding author on request.

Acknowledgments: The authors are thankful to Planet Labs and Google Earth for providing PlanetScope satellite data and Google Earth images, respectively. We would also like to thank T. Peter and Usmangani Sherasiya from India's National Fish workers Forum (NFF) for their valuable time for personal interviews, which helped to enrich this research with inputs from the grassroots level. We would like to thank Manish Thavar for data gathering and pictures of the harbors. This work was supported by the Office for Developing Future Research Leaders (L-Station) and SOUSEI Support Program for Young Researcher Hokkaido University and Hirose Foundation Japan.

Conflicts of Interest: The authors declare no conflict of interest. 


\section{Appendix A}

Table A1. Comparison of economic activities at the three harbors for FY 2018-2019 and 2019-2020.

\begin{tabular}{|c|c|c|c|c|c|c|}
\hline \multirow{2}{*}{ Particulars } & \multicolumn{2}{|c|}{ Mangrol } & \multicolumn{2}{|c|}{ Veraval } & \multicolumn{2}{|c|}{ Vanakbara } \\
\hline & 2018-2019 & 2019-2020 & 2018-2019 & 2019-2020 & 2018-2019 & 2019-2020 \\
\hline $\begin{array}{l}\text { Annual Fish and Prawns } \\
\text { Catch (Metric Tonnes) }\end{array}$ & 40.45 & 41.31 & 234.15 & 238.64 & 41.57 & 42.01 \\
\hline $\begin{array}{c}\text { Number of Fisheries } \\
\text { Workers }\end{array}$ & 11,300 & 11,600 & 22,570 & 25,650 & 8570 & 8855 \\
\hline $\begin{array}{l}\text { Number of Technical and } \\
\text { Processing Workers }\end{array}$ & 2000 & 2100 & 14,700 & 16,100 & 4566 & 4794 \\
\hline $\begin{array}{c}\text { MFV Boats } \\
\text { (Trawlers/Gillnetter) }\end{array}$ & 1459 & 1497 & 3059 & 3097 & 1260 & 1275 \\
\hline FRP Boats (IBM/OBM) & 725 & 775 & 875 & 908 & 145 & 153 \\
\hline
\end{tabular}

(Source: Compiled by the Authors from the data received from Fishermen Associations at respective Harbors).
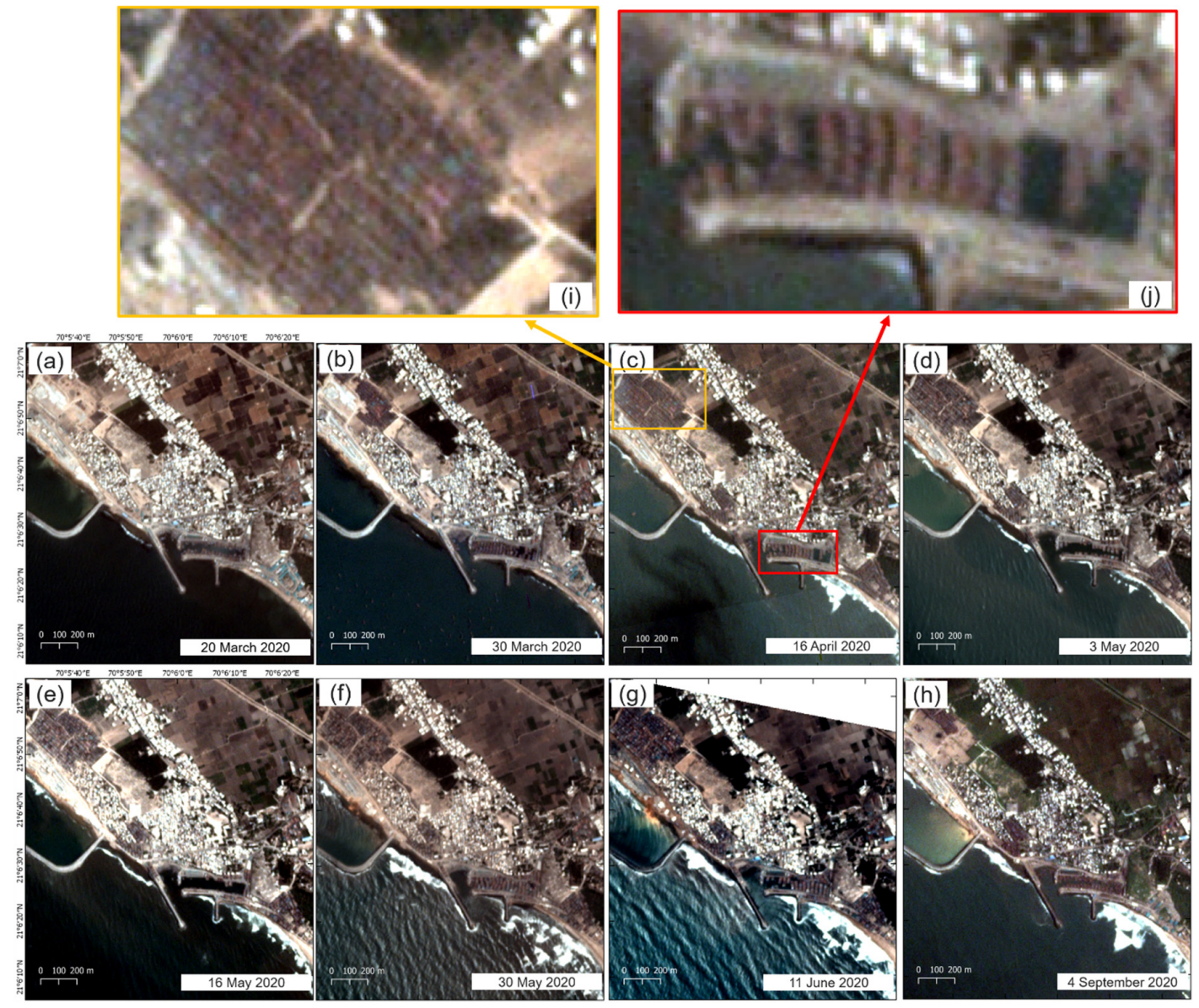

Figure A1. True-colour composite images of PlanetScope in Mangrol harbor on (a) 20 March, (b) 30 March, (c) 16 April, (d) 3 May, (e) 16 May, (f) 30 May, (g) 11 June, and (h) 4 September 2020 with two subset images (i,j) on 16 April 2020. 

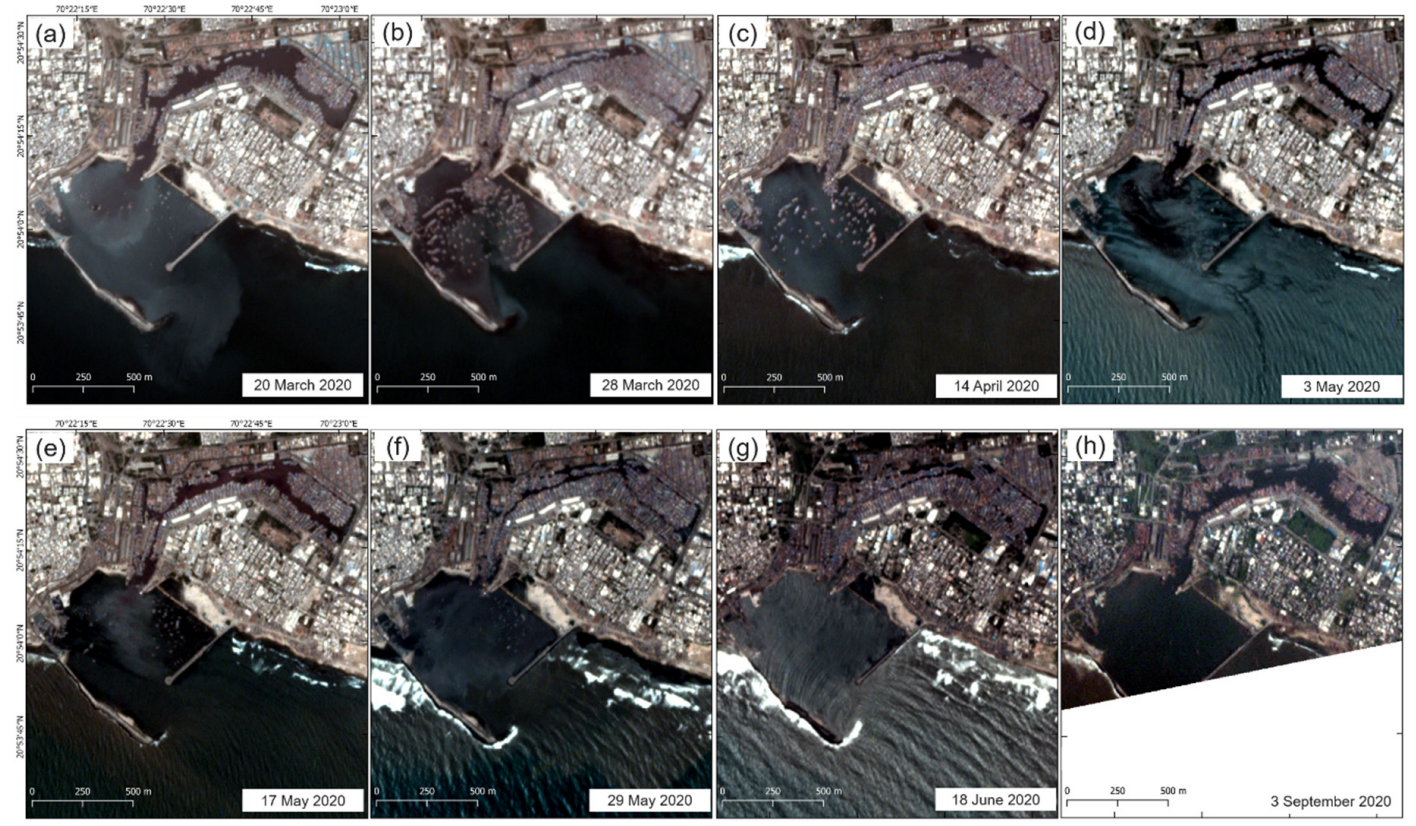

Figure A2. True-colour composite images of PlanetScope in Veraval harbor on (a) 20 March, (b) 28 March, (c) 14 April, (d) 3 May, (e) 17 May, (f) 29 May, (g) 18 June, and (h) 3 September 2020.
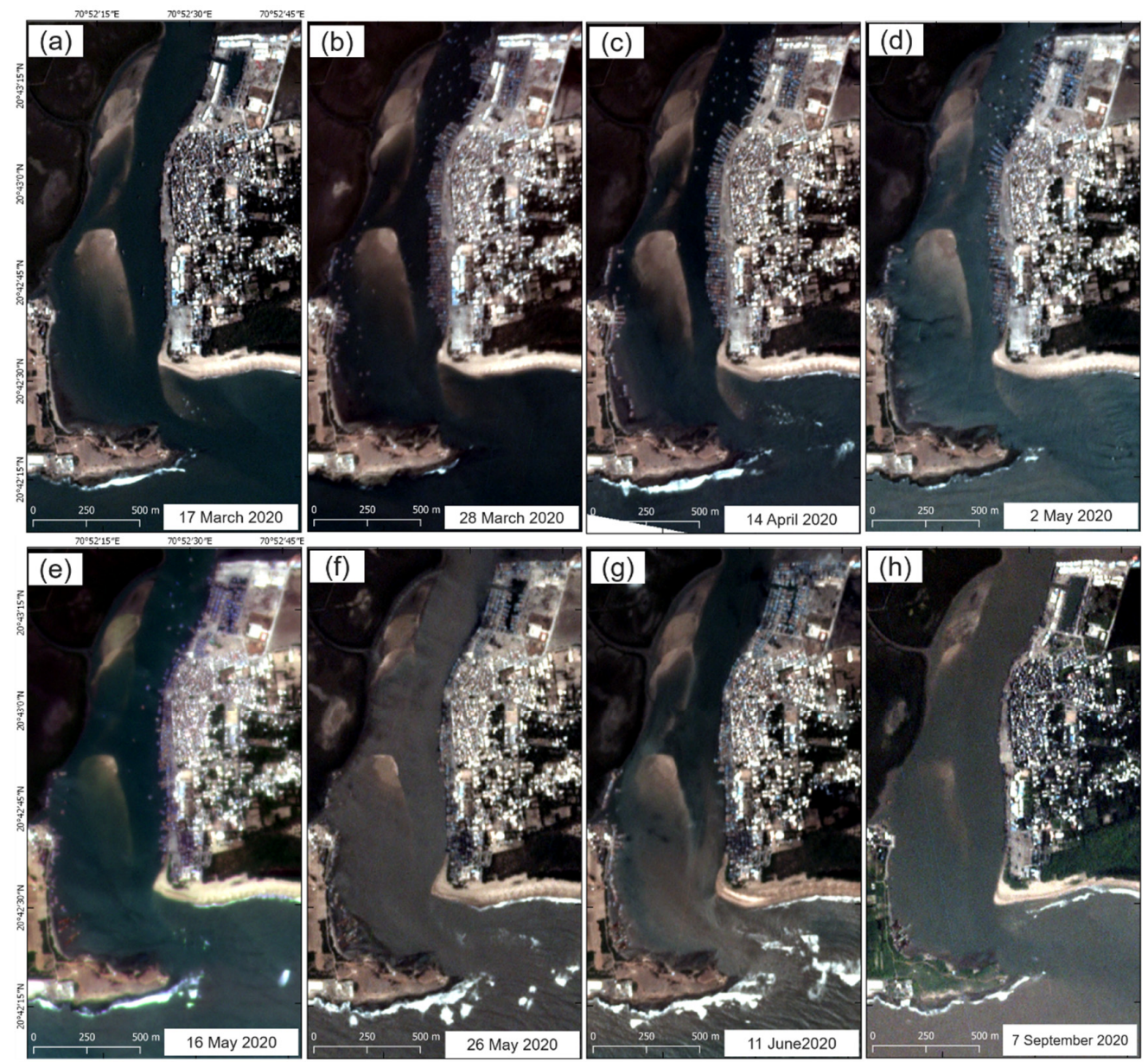

Figure A3. True-colour composite images of PlanetScope in Vanakbara harbor on (a) 17 March, (b) 28 March, (c) 14 April, (d) 2 May, (e) 16 May, (f) 26 May, (g) 11 June, and (h) 7 September 2020. 


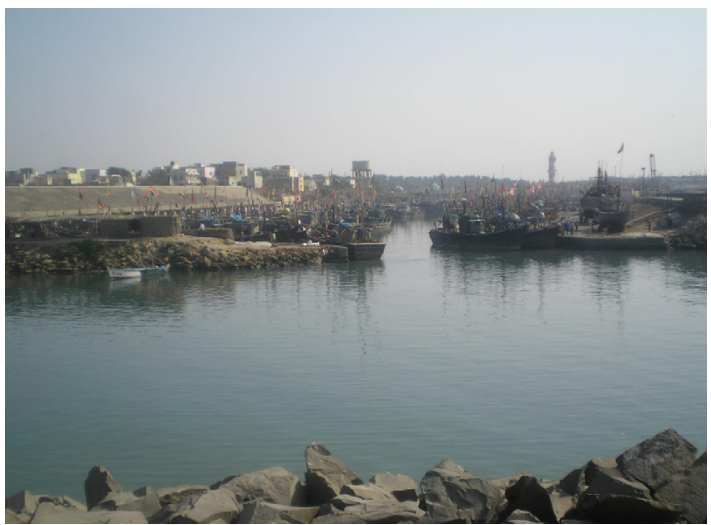

(a) Boats near harbor during the lockdown

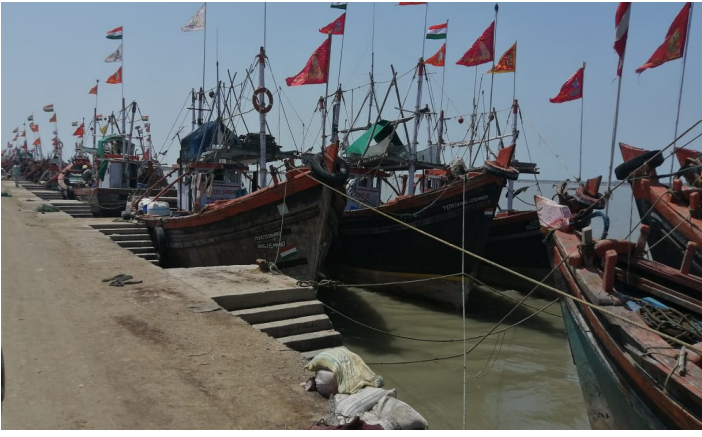

(c) Boats near harbor during the lockdown

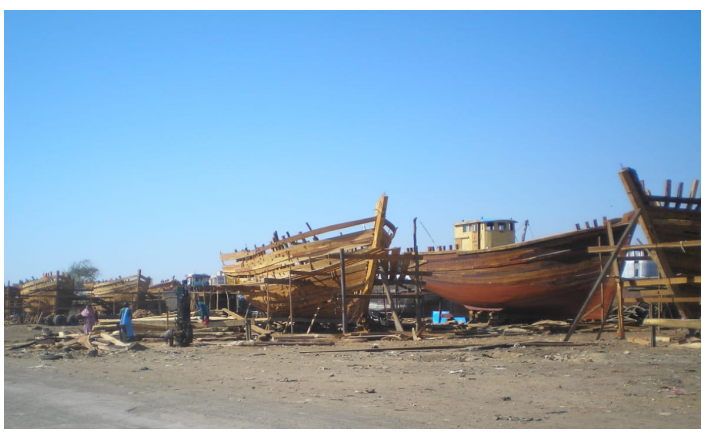

(e) maintenance of vessels in monsoon season

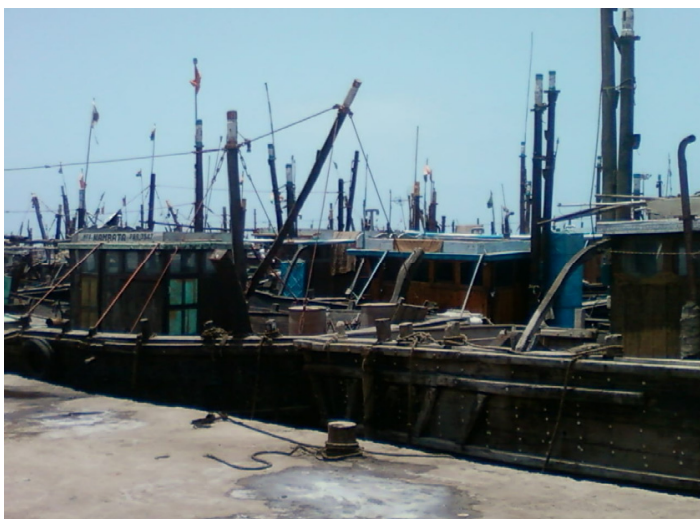

(b) Boats near harbor during the lockdown

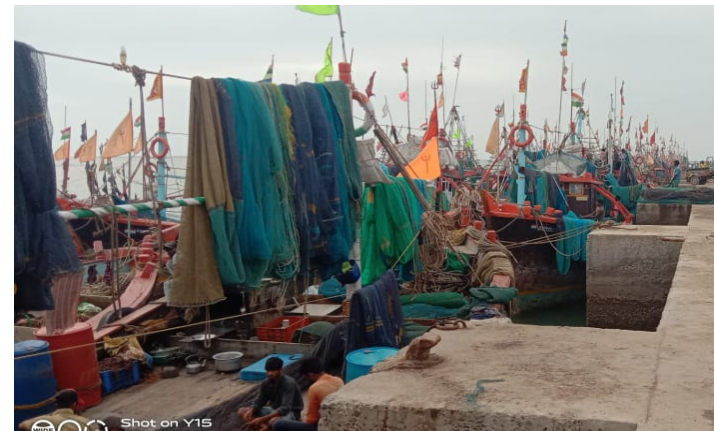

(d) Boats near harbor during the lockdown

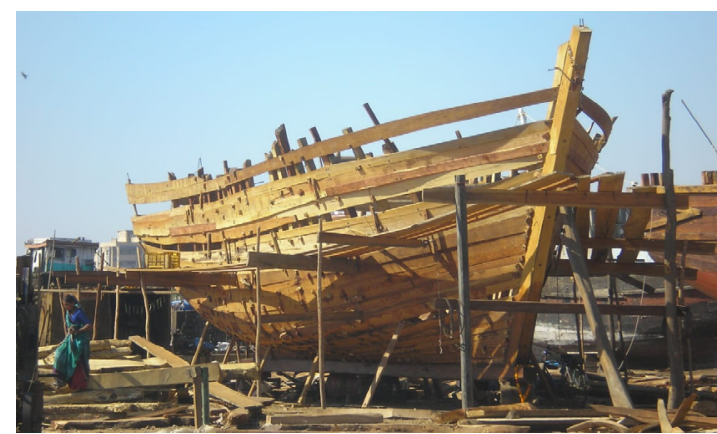

(f) maintenance of vessels in monsoon season

Figure A4. Field photographs of the vessels in the harbors.

\section{References}

1. Gopinath, G. The Great Lockdown: Worst Economic Downturn Since the Great Depression. Available online: https://blogs.imf. org/2020/04/14/the-great-lockdown-worst-economic-downturn-since-the-great-depression/ (accessed on 31 May 2020 ).

2. Yunus, A.P.; Masago, Y.; Hijioka, Y. COVID-19 and Surface Water Quality: Improved Lake Water Quality during the Lockdown. Sci. Total Environ. 2020, 731, 139012. [CrossRef]

3. Avtar, R.; Kumar, P.; Supe, H.; Jie, D.; Sahu, N.; Mishra, B.; Yunus, A. Did the COVID-19 Lockdown-Induced Hydrological Residence Time Intensify the Primary Productivity in Lakes? Observational Results Based on Satellite Remote Sensing. Water 2020, 12, 2573. [CrossRef]

4. Tripathi, A. Covid-19 Effect on Micro, Small and Medium Enterprises (MSMEs). Available online: https://timesofindia.indiatimes. com/blogs/agyeya/covid-19-affect-on-micro-small-and-medium-enterprises-msmes/ (accessed on 31 May 2020).

5. The Hindu. Moody's Revises India's 2020 GDP Contraction Estimate to $8.9 \%$ from $9.6 \%$. Available online: https://www. thehindu.com/business /Economy/moodys-revises-indias-2020-gdp-forecast-to-89-from-96/article33082321.ece\# (accessed on 1 December 2020).

6. Sharma, Y.S. 27 Million Youth in Age Group of 20-30 Years Lost Jobs in April: CMIE. Available online: https:/ / economictimes. indiatimes.com/news/economy/indicators/unemployment-rate-dips-to-23-97-data-from-cmie-shows/articleshow/756893 70.cms?from $=\mathrm{mdr}$ (accessed on 31 May 2020). 
7. Desai, P.N. Coastal Marine Environment of Gujarat. In Proceedings of the Science, Technology, Coastal Zone Management and Policy; Allied Publishers: Mangalore, Karnataka, India, November 2000; pp. 115-123.

8. Desai, P.N. India's S\&T Cooperation with the Developing Countries. World J. Sci. Technol. Sustain. Dev. 2012, 9, 28-37. [CrossRef]

9. Desai, P.N. India's STI Policy towards COVID-19. Transdisciplinary Research Cluster on Sustainability Studies (TRCSS), Working Paper 9; Jawaharlal Nehru University (JNU): New Delhi, India, 2020.

10. The Economist. Scientific Research on the Coronavirus is Being Released in a Torrent. Available online: https://www.economist. com/science-and-technology/2020/05/07/scientific-research-on-the-coronavirus-is-being-released-in-a-torrent (accessed on 31 May 2020).

11. UNCTAD. UNCTAD-World Oceans Day 2020 Report. In Proceedings of the The Blue Economy and COVID-19 Pandemic: New Challenges, Recovery Measures and Resilience, 4 June 2020; UNCTAD: Geneva, Switzerland, 2020.

12. CBD. The "Blue Economy" Is Critical to Food Security and the Fight Against Poverty. Available online: https://www.cbd.int/ article/waterforbiodiversity-2 (accessed on 11 May 2020).

13. Fisheries Statistics Division. Handbook on Fisheries Statistics of India 2018; Department of Fisheries, Ministry of Fisheries, Animal Husbandry \& Dairying, Government of India: New Delhi, India, 2019; p. 190.

14. MoF. Union Budget of India; Ministry of Finance (MoF), Government of India: New Delhi, India, 2019.

15. The World Bank. The Blue Economy. Available online: https://www.worldbank.org/en/news/infographic/2017/06/06/blueeconomy (accessed on 20 May 2020).

16. Sathiadhas, R.; Biradar, R.S. Fisheries in the Development of Indian Economy. In Proceedings of the National Conference on Fisheries Economics, Extension and Management, Mumbai, India, 5-6 January 2000; Central Marine Fisheries Research Institute (CMFRI): Mumbai, India, 2000; pp. 1-20.

17. Mathew SJ, P.T. Marine Fisheries and the Traditional Fisher folk. In Between the Sea and the Sky: Lived Religion on the Seashore; Fortress Press: Minneapolis, MN, USA, 2020; p. 157. ISBN 978-1-5064-5200-5.

18. Patil, N.R.; Peter, T. National Fishworkers Forum's (NFF) Communication with Minister of State for the Ministry of Fisheries, Animal Husbandry \& Dairying, Government of India. Available online: https://nffindia.org/wp/category/pressstatement/ (accessed on 30 May 2020).

19. Ujjania, N.C.; Patel, A.N. Socio-Economic Status of Fishermen Community of Danti Village InValsad District (Gujarat) India. Emerg. Trends Dev. Res. 2011, 18, 25-30.

20. Ghoshal, S. Fisheries Sector Expected to Touch Rs 1.5 lakh Crore by 2020: Assocham. Available online: https://economictimes. indiatimes.com/news/economy / agriculture/fisheries-sector-expected-to-touch-rs-1-5-lakh-crore-by-2020-assocham/ articleshow /58804708.cms?from $=$ mdr (accessed on 20 May 2020).

21. Dey, M.M.; Rab, M.A.; Paraguas, F.J.; Piumsombun, S.; Bhatta, R.; Alam, M.F.; Ahmed, M. Fish Consumption and Food Security: A Disaggregated Analysis by Types of Fish and Classes of Consumers in Selected Asian Countries. Aquac. Econ. Manag. 2005, 9, 89-111. [CrossRef]

22. Johnson, D. Wealth and Waste: Contrasting Legacies of Fisheries Development in Gujarat since 1950s. Econ. Political Wkly. 2001, 1095-1102.

23. Commissioner of Fisheries. Fisheries at Glance. Available online: https://cof.gujarat.gov.in/Images/commissioneroffisheries / pdf/Fisheries-at-Glance-Jan-2011-12-08-2011.pdf (accessed on 30 May 2020).

24. Sherasiya, U. (India's National Fish Workers Forum (NFF), Kerala, India). Personal communication, 2020.

25. Masani, A.K.H. Catch Composition and Economic Analysis of Trawlers Operating from Veraval Fishing Harbour. Master's Thesis, Junagadh Agricultural University, Veraval, Gujarat, India, 2012.

26. Jamwal, N. Lockdown Enforced When They Were at Sea-So More Than a Lakh of Fishers Now Wait in Deep Waters. Available online: https: / / en.gaonconnection.com/lockdown-enforced-when-they-were-at-sea-so-lakhs-of-fishers-now-wait-in-deepwaters / (accessed on 19 May 2020).

27. Vohra, S. India's Lockdown Has Put 16 Million Fisherfolk Out of Business. Here's How They're Coping. Available online: https: / / scroll.in/article/959062/indias-lockdown-has-put-16-million-fisherfolk-out-of-business-heres-how-theyre-coping (accessed on 19 May 2020).

28. Vohra, S. India's Fishers Have Been Crushed by COVID-19. Available online: https://www.hakaimagazine.com/news/indiasfishers-have-been-crushed-by-covid-19/ (accessed on 11 May 2020).

29. Roshan, M. A Study of Migrant Fishers from Andhra Pradesh in the Gujarat Marine Fishing Industry; International Collective in Support of Fishworkers: Chennai, India, 2017; p. 50.

30. Khakhariya, N. 25K Fishermen Stranded in Boats in Gujarat Coasts. Available online: https:/ timesofindia.indiatimes.com/city/ rajkot/25k-fishermen-stranded-in-boats-in-gujarat-coasts/articleshow /74938000.cms (accessed on 19 May 2020).

31. Satheesh, S. Indian Fishermen Stranded at Ports Amid Coronavirus Lockdown. Available online: https://www.aljazeera.com/ news / 2020/04/indian-fishermen-stranded-ports-coronavirus-lockdown-200426050800842.html (accessed on 11 May 2020).

32. MHA. Third Addendum to the Consolidated Guidelines by Ministry of Home Affairs (MHA); Government of India: New Delhi, India. Available online: https:/ / www.mha.gov.in/sites/default/files/3rd\%20Addendum\%20dated\%202.4.2020\%20to\%20Lockdown\% 20measures_0.pdf (accessed on 15 August 2020).

33. Santos, A.M.P. Fisheries Oceanography Using Satellite and Airborne Remote Sensing Methods: A Review. Fish. Res. 2000, 49, 1-20. [CrossRef] 
34. Chassot, E.; Bonhommeau, S.; Reygondeau, G.; Nieto, K.; Polovina, J.J.; Huret, M.; Dulvy, N.K.; Demarcq, H. Satellite Remote Sensing for an Ecosystem Approach to Fisheries Management. ICES J. Mar. Sci. 2011, 68, 651-666. [CrossRef]

35. Polovina, J.J.; Howell, E.A. Ecosystem Indicators Derived from Satellite Remotely Sensed Oceanographic Data for the North Pacific. ICES J. Mar. Sci. 2005, 62, 319-327. [CrossRef]

36. Yen, K.-W.; Lu, H.-J.; Chang, Y.; Lee, M.-A. Using Remote-Sensing Data to Detect Habitat Suitability for Yellowfin Tuna in the Western and Central Pacific Ocean. Int. J. Remote Sens. 2012, 33, 7507-7522. [CrossRef]

37. Dulvy, N.; Chassot, E.; Heymans, J.; Hyde, K.; Pauly, D.; Platt, T.; Sherman, K. Climate Change, Ecosystem Variability and Fisheries Productivity; The International Ocean-Colour Coordinating Group (IOCCG): Dartmouth, Canada, 2009; pp. 11-28.

38. Zainuddin, M.; Kiyofuji, H.; Saitoh, K.; Saitoh, S.-I. Using Multi-Sensor Satellite Remote Sensing and Catch Data to Detect Ocean Hot Spots for Albacore (Thunnus Alalunga) in the Northwestern North Pacific. Deep Sea Res. Part II Top. Stud. Oceanogr. 2006, 53, 419-431. [CrossRef]

39. He, H.; Lin, Y.; Chen, F.; Tai, H.-M.; Yin, Z. Inshore Ship Detection in Remote Sensing Images via Weighted Pose Voting. IEEE Trans. Geosci. Remote Sens. 2017, 55, 3091-3107. [CrossRef]

40. Klemas, V. Fisheries Applications of Remote Sensing: An Overview. Fish. Res. 2013, 148, 124-136. [CrossRef]

41. Snapir, B.; Waine, T.; Biermann, L. Maritime Vessel Classification to Monitor Fisheries with SAR: Demonstration in the North Sea. Remote Sens. 2019, 11, 353. [CrossRef]

42. Avtar, R.; Aggarwal, R.; Kharrazi, A.; Kumar, P.; Kurniawan, T.A. Utilizing Geospatial Information to Implement SDGs and Monitor Their Progress. Environ. Monit. Assess. 2020, 192, 35. [CrossRef]

43. Ultra-Tech. Environment Impact Assessment for Proposed Veraval Fishery Harbour-Phase II; Ultra-Tech, Environmental Consultancy and Laboratory, Thane, Maharashtra. Prepared for the Fisheries Department Govt. of Gujarat NABET/EIA/1417/RA010. September 2017. Available online: http:/ / environmentclearance.nic.in/writereaddata/FormB/EC/EIA_EMP/20092017S7YNM2 DTVeravalEIAReportwithpagenumber.pdf (accessed on 15 August 2020).

44. Marta, S. Planet Imagery Product Specifications. Available online: https://assets.planet.com/docs/Combined-Imagery-ProductSpec-Dec-2018.pdf (accessed on 15 August 2020).

45. Supe, H.; Avtar, R.; Singh, D.; Gupta, A.; Yunus, A.P.; Dou, J.; Ravankar, A.A.; Mohan, G.; Chapagain, S.K.; Sharma, V.; et al. Google Earth Engine for the Detection of Soiling on Photovoltaic Solar Panels in Arid Environments. Remote Sens. 2020, $12,1466$. [CrossRef]

46. Kanjir, U.; Greidanus, H.; Oštir, K. Vessel Detection and Classification from Spaceborne Optical Images: A Literature Survey. Remote Sens. Environ. 2018, 207, 1-26. [CrossRef]

47. Beşbinar, B.; Alatan, A.A. Inshore Ship Detection in High-Resolution Satellite Images: Approximation of Harbors Using Sea-Land Segmentation. In Proceedings of the SPIE 9643, Image and Signal Processing for Remote Sensing XXI, 96432D; International Society for Optics and Photonics: Toulouse, France, 2015.

48. Xu, J.; Sun, X.; Zhang, D.; Fu, K. Automatic Detection of Inshore Ships in High-Resolution Remote Sensing Images Using Robust Invariant Generalized Hough Transform. IEEE Geosci. Remote Sens. Lett. 2014, 11, 2070-2074. [CrossRef]

49. Li, N.; Zhang, Q.; Zhao, H.; Dong, C.; Meng, L. Ship Detection in High Spatial Resolution Remote Sensing Image Based on Improved Sea-Land Segmentation. In Hyperspectral Remote Sensing Applications and Environmental Monitoring and Safety Testing Technology; International Society for Optics and Photonics (SPIE): Beijing, China, 2016; Volume 101560T-1, pp. 1-9.

50. Zhang, R.; Yao, J.; Zhang, K.; Feng, C.; Zhang, J. S-CNN-Based Ship Detection from High-Resolution Remote Sensing Images. Int. Arch. Photogramm. Remote Sens. Spatial Inf. Sci. 2016, XLI-B7, 423-430. [CrossRef]

51. Janyala, S. Coronavirus Lockdown: Gujarat Govt Hires Cargo Ships to Send Andhra Fishermen Home. Available online: https:/ /indianexpress.com/article/india/coronavirus-india-lockdown-gujarat-govt-hires-cargo-ships-to-send-andhrafishermen-home-6376558/ (accessed on 15 May 2020).

52. Liu, B.; Li, Y.; Zhang, Q.; Han, L. The Application of GF-1 Imagery to Detect Ships on the Yangtze River. J. Indian Soc. Remote Sens. 2017, 45, 179-183. [CrossRef]

53. Gao, B.-C. NDWI-A Normalized Difference Water Index for Remote Sensing of Vegetation Liquid Water from Space. Remote Sens. Environ. 1996, 58, 257-266. [CrossRef]

54. Congalton, R.G.; Green, K. Assessing the Accuracy of Remotely Sensed Data: Principles and Practices, 3rd ed.; CRC Press: Boca Raton, FL, USA, 2019; ISBN 978-0-429-05272-9.

55. Maxar Technologies. Imagery Basemaps. Available online: https://www.maxar.com/products/imagery-basemaps (accessed on 14 November 2020).

56. Zhan, Q.; Molenaar, M.; Tempfli, K.; Shi, W. Quality Assessment for Geo-spatial Objects Derived from Remotely Sensed Data. Int. J. Remote Sens. 2005, 26, 2953-2974. [CrossRef]

57. Whiteside, T.; Boggs, G.; Maier, S. Area-Based Validity Assessment of Single-and Multi-Class Object-Based Image Analysis. In Proceedings of the 15th Australasian Remote Sensing and Photogrammetry Conference; ARSPC: Alice Springs, Australia, 2010.

58. Kamal, M.; Phinn, S.; Johansen, K. Object-Based Approach for Multi-Scale Mangrove Composition Mapping Using MultiResolution Image Datasets. Remote Sens. 2015, 7, 4753-4783. [CrossRef]

59. Niroumand-Jadidi, M.; Bovolo, F.; Bruzzone, L.; Gege, P. Physics-Based Bathymetry and Water Quality Retrieval Using PlanetScope Imagery: Impacts of 2020 COVID-19 Lockdown and 2019 Extreme Flood in the Venice Lagoon. Remote Sens. 2020, 12, 2381. [CrossRef] 
60. Khan, S. Gujarat HC Moved Over Boat Parking Issue on Seashore. Available online: https://timesofindia.indiatimes.com/city/ ahmedabad/Gujarat-HC-moved-over-boat-parking-issue-on-seashore/articleshow/14271068.cms (accessed on 16 November 2020).

61. Gunakar, S.; Jadhav, A.; Bhatta, R. Protections for small-scale fisheries in india: A study of india's monsoon fishing ban. In The Small-Scale Fisheries Guidelines: Global Implementation; Jentoft, S., Chuenpagdee, R., Barragán-Paladines, M.J., Franz, N., Eds.; Springer International Publishing: Cham, Switzerland, 2017; pp. 291-311. ISBN 978-3-319-55074-9.

62. Mondal, M. On the Road: Tracing the Current Patterns of Fishworkers' Migration in India. Available online: https://thebastion. co.in/covid-19/on-the-road-tracing-the-current-patterns-of-fishworkers-migration-in-india/ (accessed on 10 October 2020).

63. MSSRF. COVID-19 Impact on Livelihoods of Marine Fishing Communities. Available online: https://www.mssrf.org/content/ covid19-impact-livelihoods-marine-fishing-communities-0 (accessed on 28 November 2020).

64. Sathianandan, T.V. Marine Fish Production in India-Present Status. In Proceedings of the Course Manual ICAR funded Summer School on Advanced Methods for Fish Stock Assessment and Fisheries Management; Fishery Resources Assessment Division-ICAR, Central Marine Fisheries Research Institute: Kochi, Kerala, 2017; pp. 23-27. Available online: http:/ / eprints.cmfri.org.in/12164/ 1/2-Marine\%20fish\%20production\%20in\%20India.pdf (accessed on 15 August 2020).

65. Lan, J.; Wan, L. Automatic Ship Target Classification Based on Aerial Images. In Proceedings of the SPIE 7156, 2008 International Conference on Optical Instruments and Technology; Optical Systems and Optoelectronic Instruments: Beijing, China, 2008.

66. Xu, C.; Zhang, D.; Zhang, Z.; Feng, Z. BgCut: Automatic Ship Detection from UAV Images. Sci. World J. 2014, $2014,1-11$. [CrossRef] 